University of Nebraska - Lincoln

DigitalCommons@University of Nebraska - Lincoln

2006

\title{
Muskegon Wastewater Land Treatment System: Fate and Transport of Phosphorus in Soils and Life Expectancy of the System
}

\author{
C. $\mathrm{Hu}$ \\ University of Nebraska - Lincoln \\ Tian Zhang \\ University of Nebraska - Lincoln, tzhang1@Unl.edu \\ Y. H. Huang \\ University of Nebraska - Lincoln \\ Mohamed F. Dahab \\ University of Nebraska - Lincoln, mdahab1@unl.edu \\ D. Kendrick \\ Muskegon Wastewater Treatment Plant, 8301 White Rd., Muskegon, MI \\ See next page for additional authors
}

Follow this and additional works at: https://digitalcommons.unl.edu/civilengfacpub

Part of the Civil Engineering Commons

Hu, C.; Zhang, Tian; Huang, Y. H.; Dahab, Mohamed F.; Kendrick, D.; and Surampalli, R., "Muskegon Wastewater Land Treatment System: Fate and Transport of Phosphorus in Soils and Life Expectancy of the System" (2006). Civil Engineering Faculty Publications. 12.

https://digitalcommons.unl.edu/civilengfacpub/12

This Article is brought to you for free and open access by the Civil Engineering at DigitalCommons@University of Nebraska - Lincoln. It has been accepted for inclusion in Civil Engineering Faculty Publications by an authorized administrator of DigitalCommons@University of Nebraska - Lincoln. 


\section{Authors}

C. Hu, Tian Zhang, Y. H. Huang, Mohamed F. Dahab, D. Kendrick, and R. Surampalli 


\title{
Muskegon Wastewater Land Treatment System: Fate and Transport of Phosphorus in Soils and Life Expectancy of the System
}

\author{
By C. Hu, T. C. Zhang*, D. Kendrick, Y. H. Huang, M. F. Dahab, and R. Surampalli
}

DOI: $10.1002 /$ elsc. 200620118

\begin{abstract}
The build-up of phosphorus $(\mathrm{P})$ in soil is a major factor limiting the operating life of a wastewater land treatment system. In this study, effects of long-term wastewater application on changes in chemical properties, $\mathrm{P}$ profiles, and $\mathrm{P}$ adsorption capacity were evaluated in soils of the Muskegon wastewater land treatment plant that has been treating wastewater for $>30$ years. Results indicate that the major soil properties have been changed. In the $15 \mathrm{~cm}$ topsoil, the $\mathrm{pH}$ increased from 5-6 in 1973 to 7.4-7.8 in 2003; the soil's total organic carbon (TOC) increased by 10-71 \%; and the level of exchangeable $\mathrm{Ca}$ in 2003 is 8-9 times higher than that in 1973 . The amount of $\mathrm{Ca} / \mathrm{Mg}$ absorbed in the soil affects the $\mathrm{P}$ adsorption capability of the soil; Ca- and Mg-bound $\mathrm{P}$ accounts for $>70 \%$ of the total $\mathrm{P}$ adsorbed in the soil. The net $\mathrm{P}$ accumulated in the Rubicon soil increased from $\sim 700$ in 1993 to $\sim 1345 \mathrm{~kg} / \mathrm{ha}$ soil in 2001, but the plant available P varied between $\sim 100-500 \mathrm{~kg} / \mathrm{ha}$ soil during the same period, indicating a large amount of the applied $\mathrm{P}$ has become the fixed $\mathrm{P}$ that is unavailable to plants. $\mathrm{P}$ sorption in the soil consists of a fast adsorption and a slow transformation process. The soil's maximum $\mathrm{P}$ sorption capacity $\left(\mathrm{P}_{\max }\right)$ (based on 1-day isotherm tests) has been increased by $\sim 2-4$ times since 1973; the actual $\mathrm{P}_{\max }$ of the Muskegon soils could be much higher than the 1-day $\mathrm{P}_{\max }$. Therefore, the life expectancy of the Muskegon system has been extended significantly with the application of wastewater.
\end{abstract}

\section{Introduction}

Until the 1970s, most conventional municipal wastewater treatment systems could reduce biochemical oxygen demand (BOD) in wastewater to a satisfactory level, but only achieved limited nutrient removal from domestic wastewater. As a result, significant amounts of nitrogen and phosphorus $(\mathrm{P})$ were discharged into the environment. As an alternative, wastewater land treatment was introduced as a tertiary treatment technology. In 1974, the Muskegon wastewater land treatment system was initiated in the backdrop as a large-scale demonstration project.

When the Muskegon plant was designed, the life expectancy of the system was estimated to be about 25-50 years $[1,2]$. This estimation was based on the soil's $P$ maximum adsorption capacity $\left(\mathrm{P}_{\max }\right)$ that was obtained by conducting one-day $\mathrm{P}$ adsorption isotherm tests [2]. On the basis of long-term observation, the build-up of $\mathrm{P}$ in the soil of a land treatment system can be a major factor affecting the life expectancy of the system [1]. As $\mathrm{P}$ is added to the soil through application of wastewater, it can be immobilized by organic matter, adsorbed (or absorbed) by soil particles, or quickly react with other ions in the soil to form insoluble precipitates. Although crop uptake can account for $\mathrm{P}$ removals in the range of $20-59 \mathrm{~kg} /$ ha-year [1], the level of $\mathrm{P}$ in the irri-

[*] C. Hu, T. C. Zhang (author to whom correspondence should be addressed, e-mail: tzhang@unomaha.edu), Y. H. Huang, M. F. Dahab, Civil Engineering Department, University of Nebraska-Lincoln, Lincoln, NE, 68582-0531, USA; D. Kendrick, Muskegon Wastewater Treatment Plant, 8301 White Rd., Muskegon, MI 49442, USA; R. Surampalli, U.S. EPA, Region 7, 901 N. $5^{\text {th }}$ St., Kansas City, KS 66101, USA. gated soil could steadily increase if the $\mathrm{P}$ mass loading rate is higher than the crop uptake rate. The soil maximum $\mathrm{P}$ adsorption capacity can be eventually reached after long-term wastewater application, resulting in $\mathrm{P}$ leaching in percolate of the land treatment system. To avoid an accelerated eutrophication in the aquatic system that receives effluent of a wastewater land treatment system, the $\mathrm{P}$ concentration in the effluent must be sufficiently low.

The records of the Muskegon plant has proven that the plant can be successful for more than 30 years, but how long will it take $\mathrm{P}$ to saturate the soil in a land treatment system? Many approaches have been proposed to describe the nature and the rate of the reaction of $\mathrm{P}$ with soil. Enfield et al. [3] evaluated 25 mineral soils that represented a wide range of physical and chemical properties; they found that correlating physical/chemical properties with the regression coefficients of five P kinetic models was unsuccessful. Although it was possible to fit experimental sorption data to kinetic models, none of the five models adequately described the sorption of $\mathrm{P}$ in batch equilibrium studies. These results are anticipated because $\mathrm{P}$ sorption (including adsorption, absorption, and precipitation) involves several different kinetic regions, such as a fast reaction within the first minute (or few hours) of reaction, and a steady slow reaction [4-9].

Several models have been developed to incorporate P kinetics with its transport processes [10-16]. These models can describe short-term laboratory experiments satisfactorily; they are also useful for design and operation of land treatment systems. In spite of these aforementioned studies, information is very limited on how to use kinetics and models related to $\mathrm{P}$ fate and transport to predicate the life expec- 
tancy of a land treatment system. In addition, attempts at correlating the performance of a wastewater land treatment system with the soil's physical/chemical properties and the life expectancy of the system have not been reported.

The goal of this study was to provide some insights on the effects of long-term wastewater application on (i) soil properties, (ii) $\mathrm{P}$ distributions in the soil, (iii) the $\mathrm{P}$ adsorption capacity of the soil, and (iv) the life expectancy of a land treatment system. The Muskegon wastewater land treatment system was selected to approach this goal because the Muskegon system has been operating for more than 30 years and can provide critical information related to this study.

The specific objective of this study was to estimate $\mathrm{P}$ leaching potential and the life expectancy of the Muskegon system based on batch tests, records of the long-term performance of the Muskegon system, changes in major chemical properties and $\mathrm{P}$ sorption capacity in Muskegon soils, and mass balance principles.

\section{Materials and Methods}

\subsection{Sites Description}

Situated near Michigan Lake, the Muskegon County wastewater land treatment system is one of the largest land treatment systems in the USA and has been operating since 1974. The facility is located on 4,460 ha (11,000 acres) of sandy, unproductive soil. The system consists of collection, transmission, aeration, storage, irrigation, soil, crop, and drainage components. Currently, there are 53 fields in circular shape on the site, with a total area of 2080 ha (5200 acres) of farmland. There are four major types of sandy soil on the site: Rubicon, Roscommon, Augers, and Granby. Corn, alfalfa, and soybean are rotationally planted for improved system performance. Originally, these soils were very friable and strongly acid ( $\mathrm{pH}=3-5)$ except the Granby, which is neutral at the top and slightly acid at the subpart [17].

The facility has a design treatment capacity of $158,970 \mathrm{~m}^{3} / \mathrm{d}$ (42 MGD). In the early 1980s, the facility treated $124,905 \mathrm{~m}^{3} / \mathrm{d}$ (33 MGD). Due to the shrinking industry within the service area and application of water conservation technologies, the facility currently treats only $98,410 \mathrm{~m}^{3} / \mathrm{d}$ (26 MGD). Among the contributing sources, $\sim 50 \%$ comes from a paper mill, $\sim 25 \%$ from other industries and $\sim 25 \%$ from domestic wastewater. Before being sprayed on the soil, wastewater is pretreated by full-mixing basins and aerating-settling basins, then stored in two storage lagoons with a total capacity of $2 \times 10^{7} \mathrm{~m}^{3}$ (an area of 680 ha and a depth of 1-3 m). The two storage lagoons provide sufficient storage capacity for the winter period when water cannot be applied to the fields. The pretreatment processes remove $>90 \%$ of the original organic compounds and $\sim 30 \%$ of $\mathrm{P}$ in the wastewater [18].

The irrigation distribution system consists of pumping stations, a network of distribution force mains and center pivot irrigation rigs. The processed wastewater is sprinkled through irrigation rigs onto the circular fields. The Muskegon land treatment plant consists of both a slow-rate (SR) system ( $2080 \mathrm{ha})$ with an average wastewater application rate of $7.6 \mathrm{~cm} /$ week ( $3 \mathrm{in} /$ week) for $\sim 180$ days and a rapid infiltration system ( $\sim 60 \mathrm{ha})$. Specifically, for the SR system, the wastewater application rate is $\sim 2.54 \mathrm{~cm} / \mathrm{d}(1 \mathrm{in} / \mathrm{d})$ for $\sim 180$ days for Rubicon soil (the best performance soil) and Roscommon soil (the $2^{\text {nd }}$ best) and $\sim 0.8-1.5 \mathrm{~cm} / \mathrm{d}$ (0.3-0.6 in/d) for $\sim 180$ days for Augres. Between 1974 and 2001, precipitation, including snow, averages $85.1 \mathrm{~cm} / \mathrm{yr}$ ( $33.5 \mathrm{in} / \mathrm{yr})$; the average annual evaporation is $76.2 \mathrm{~cm}$ (30 in).

\subsection{Soil and Wastewater Sampling}

Soil samples were taken from fields 6 (Rubicon), 29 (Roscommon), and 17 (Augers) using a $5.1 \times 15.2 \mathrm{~cm}$ $(2 \times 6$ inches $)$ soil sampling kit (AMS Inc, ID). At each field, three soil core samples were taken along the depth of the soil for profiling $\mathrm{P}$ and soil properties. Soil samples were divided into $15-\mathrm{cm}$ (6-in) depth increments from the surface to the groundwater table $(\sim 2.4-2.7 \mathrm{~m})$. The Muskegon plant provided some original soil cores (sampled in 1973, 1976, and 1979) that were air dried with each soil core in its own container and then stored at room temperature $\left(\sim 22{ }^{\circ} \mathrm{C}\right)$. Water samples were collected from the sprinkler (influent) and the drainage (effluent) of the corresponding fields.

Once in the laboratory, each of these soil samples was dried at room temperature, passed through a 2-mm sieve, and stored in a glass jar (bottle) with a cap. In this study, one composite soil sample was made for each depth increment by mixing the same quantity of the three sieved soil samples that were taken at the same depth. Detailed information on procedures of sampling and sample treatment in the laboratory were reported in $[19,20]$.

\subsection{P Adsorption Isotherms}

In this study, both short-term (0-24 h) and long-term $(0-2000 \mathrm{~h})$ isotherm tests were conducted. For short-term tests, $\mathrm{P}$ sorption isotherms were obtained by continuously agitating batch reactors for $24 \mathrm{~h}$ [21]. Each batch reactor was a $50 \mathrm{~mL}$ equilibration tube containing $25 \mathrm{~mL}$ of $0.01 \mathrm{M}$ $\mathrm{CaCl}_{2}$ solution, $2 \mathrm{~g}$ of air-dried soil and a specified $\mathrm{P}$ concentration of $0.5,1,2,5,7,10 \mathrm{mg} / \mathrm{L}$, respectively. For long-term tests, two sets of the initial $\mathrm{P}$ concentration in the batch reactors (tubes) were $0.5,1,2,5,7,10 \mathrm{mg} / \mathrm{L}$ and 5, 7, 10, 20, 30, $40 \mathrm{mg} / \mathrm{L}$. For each $\mathrm{P}$ concentration, multiple batch reactors (= 8 for set 1 and $10-11$ set 2 ) were prepared. At each predetermined time interval, one reactor was removed from the rotating box (with a $30 \mathrm{rpm}$ rotating speed) and sacrificed for sample analysis. The predetermined time intervals were $1,3.5,24,48.5,98.5,142.5,286.5$, and $389 \mathrm{~h}$ for the first set of the test, and were similar for the second set, plus 2 or 3 addi- 
tional intervals (e.g., 300, 1000, and $2000 \mathrm{~h}$ ). Results of these isotherm tests were used to calculate the $\mathrm{P}_{\max }$ of the soils using the Langmuir equation [21].

\subsection{Analytical Methods}

Unless otherwise indicated, all aqueous solutions were prepared with deionized water (DI) with resistivity between 15 and 18 megohm-cm (Barnstead Nanopure series 550, Barnstead/ Thermolyne Co., Dubuque, IA). All commercially available chemicals were from VWR Scientific, IL with ACS (American Chemistry Society) or high performance liquid chromatography (HPLC) grade and used as received. All tests and analyses were conducted at room temperature $\left(24 \pm 1{ }^{\circ} \mathrm{C}\right)$. In this study, the average of the triplicates $(n=3)$ of a composite soil (sampled at 3 locations) at each depth is reported.

Also, different $\mathrm{P}$ forms sorbed in the soils were analyzed, including labile $\mathrm{P}$ [22], Fe-/Al-associated P, Ca-/Mg-associated $\mathrm{P}$ [23], and total $\mathrm{P}$ [24]. In addition, other soil properties were measured, such as soil $\mathrm{pH}$ [25], oxalate-extractable $\mathrm{Al}$ (Ox-Al), Fe (Ox-Fe), and P (Ox-P) [26,27], exchangeable $\mathrm{Ca} / \mathrm{Mg}[19,20,28]$, total organic matter [29], and the $\mathrm{CaCO}_{3}$ content of the soil samples [30]. Detailed information on procedures of analytical methods was reported in $[19,20]$.

\section{Results and Discussion}

\subsection{System Performance and Mass Balance of $P$}

The records of the Muskegon plant show that the land treatment system has been successfully producing high quality effluent (see Tab. 1). The influent wastewater has a $\mathrm{pH}$ near 7 with a total $P$ of about $3 \mathrm{mg} / \mathrm{L}$ and a relatively high concentration of some salts. The pretreatment processes remove $>90 \%$ of the original organic compounds and $\sim 30 \%$ of $\mathrm{P}$ in the wastewater before the wastewater enters into the storage lagoons [18]. The storage lagoons further remove some contaminants; $<1 \%$ of the water's original organic matter remains at this point. Over the period of operation, all the major quality parameters of the discharges from both the slow rate and rapid infiltration systems are significantly better than the respective discharge standards. On average, the pretreated wastewater before irrigation contains 2-3 mg $\mathrm{TP} / \mathrm{L}, 20-30 \mathrm{mg} \mathrm{BOD}_{5} / \mathrm{L}, 5 \mathrm{mg} \mathrm{TN} / \mathrm{L}, \sim 123 \mathrm{mg} \mathrm{Ca}^{2+} / \mathrm{L}$, $\sim 20 \mathrm{mg} \mathrm{Mg}{ }^{2+} / \mathrm{L},<0.5 \mathrm{mg} \mathrm{Fe}^{2+}$ and $\mathrm{Fe}^{3+} / \mathrm{L},<20 \mathrm{mg} \mathrm{Al}^{3+} / \mathrm{L}$, and a $\mathrm{pH}$ of about 8.5. After filtering through the soil media, the BOD, suspended solids, and P levels are lower than 2,6, and $0.03 \mathrm{mg} / \mathrm{L}$, respectively, which are well below the discharge permit requirements. However, the $\mathrm{Ca}, \mathrm{Mg}, \mathrm{Fe}$, and $\mathrm{Al}$ concentrations are more or less the same as those before irrigation. Moreover, P can be removed by the RI system; the $\mathrm{P}$ concentration of effluent of the RI system can be as low as $0.02 \sim 0.04 \mathrm{mg} / \mathrm{L}$. These results indicate that sandy soils with high hydraulic conductivities (30-80 cm/h for Rubicon, Roscommon and Augres [18]) are feasible for wastewater land treatment.

Over the years of operation, water balance has been monitored by tracking the amount of water applied to each field, the annual precipitation and the flow rate in the outfalls. In general, Rubicon fields have been irrigated most intensively, followed by Augres fields and Roscommon fields. Because of their poor permeability ( $16 \mathrm{~cm} / \mathrm{h}$ for horizon Ap), Granby fields have been receiving about $3-4 \%$ of the wastewater. According to the record, about $62 \%$ of the water received by the field (i.e., irrigation + rainfall precipitation) would be recovered in the drainage effluent. Evaportranspiration may account for most of the $38 \%$ water loss, but an unknown percentage of the seepage may become groundwater.

$\mathrm{P}$ introduced by irrigation could either be assimilated by crop, retained in the soil, or drained after penetrating the soil layer. The mass of $\mathrm{P}$ applied to each field is computed by multiplying the amount of water with its $\mathrm{P}$ concentration. About $25 \%$ of the $\mathrm{P}$ in the wastewater applied to the field was removed by cropping, which was estimated by multiplying the harvest with the $\mathrm{P}$ content of the specific crop. The $\mathrm{P}$ loss by drainage is approximated by assuming that the average $\mathrm{P}$ concentration in the percolate of each field is $0.04 \mathrm{mg} / \mathrm{L}$ and that $62 \%$ of water received from the field will be drained. On the basis of mass balance principles, the total net accumulated $\mathrm{P}$ in the soil $\left(\mathrm{P}_{\text {total }}\right)$ can be calculated as follows:

$\mathrm{P}_{\text {total }}=\mathrm{P}$ added by irrigation $-\mathrm{P}$ consumed by crops $-\mathrm{P}$ lost through drainage

The P balance during the period of 1974-2001 in each field is summarized in this study. The results show that the land treatment system can intercept most of the P applied (i.e., about $99 \%$ of the applied $\mathrm{P}$ being retained) [19].

\subsection{Effects of Wastewater Application on Soil's Chemical Properties}

On intuition, sandy soil in general may have much smaller $\mathrm{P}$ adsorption capacity and much lower organic $\mathrm{C}$ content than loamy soil. A logical question is how can the Muskegon system last for $>30$ years successfully without any major $P$ leaching in its effluent? Investigation on changes in soil chemical properties can answer this question, to a certain degree.

As shown in Tab. 2, the chemical properties of the Muskegon soils have changed, probably due to the long-term application of the wastewater with a high $\mathrm{pH}(\sim 8.5)$ and a high salt content (e.g., $\mathrm{Ca}, \mathrm{Mg}$, etc.). The soil $\mathrm{pH}$ increased from 5 $\sim 6$ in 1973 to $>7$ in 2003 (see Tab. 1). The Fe precipitates still remain in the soils, while the extractable Al was lost through the drainage water [20]. One of the most important changes in the Muskegon soils is that the exchangeable $\mathrm{Ca}$ concentrations in 2003 are almost ten times higher than those in 1973, while the total Ca concentration does not in- 
Sci. Full Paper

Table 1. Influent and effluent characteristics of Muskegon wastewater treatment plant ${ }^{\mathrm{a}}$.

\begin{tabular}{|c|c|c|c|c|c|c|c|c|}
\hline \multirow{3}{*}{ Parameter } & \multicolumn{2}{|c|}{ Influent $^{\text {b) }}$} & \multicolumn{6}{|c|}{ Plant Effluent } \\
\hline & \multirow[t]{2}{*}{ Plant } & \multirow[t]{2}{*}{ Field } & \multicolumn{3}{|c|}{ Outfall 1} & \multicolumn{3}{|c|}{ Outfall 2} \\
\hline & & & Min & Ave & $\operatorname{Max}$ & Min & Ave & Max \\
\hline BOD $[\mathrm{mg} / \mathrm{L}]$ & 257 & 5.15 & 0 & $<2$ & $<2$ & 0 & $<2$ & $<2$ \\
\hline $\mathrm{pH}$ & 7.08 & 8.5 & 7.01 & - & 8.00 & 7.01 & - & 7.28 \\
\hline TSS $[\mathrm{mg} / \mathrm{L}]$ & 505 & ND & 2.0 & 6.91 & 19 & 0 & 3.41 & 7.00 \\
\hline VSS $[\mathrm{mg} / \mathrm{L}]$ & 302 & ND & - & - & - & - & - & - \\
\hline Total P $[\mathrm{mg} / \mathrm{L}]$ & 3.06 & 1.88 & 0.02 & 0.03 & 0.05 & 0.02 & 0.02 & 0.04 \\
\hline $\mathrm{Cl}^{-}[\mathrm{mg} / \mathrm{L}]$ & 254 & $\mathrm{ND}$ & 90.9 & 106 & 118 & 137 & 200 & 216 \\
\hline TKN [mg/L] & 15.6 & ND & - & - & - & - & - & - \\
\hline $\mathrm{NH}_{3}[\mathrm{mg} / \mathrm{L}]$ & 7.24 & 1.32 & 0.03 & 0.09 & 0.15 & 0 & 0.04 & 0.22 \\
\hline $\mathrm{NO}_{2}^{-}[\mathrm{mg} / \mathrm{L}]$ & $\mathrm{ND}^{\mathrm{c})}$ & ND & 0.019 & 0.03 & 0.036 & 0.034 & 0.04 & 0.057 \\
\hline $\mathrm{NO}_{3}{ }^{-} / \mathrm{NO}_{2}^{-}[\mathrm{mg} / \mathrm{L}]$ & ND & $\mathrm{ND}$ & 0.524 & 0.080 & 1.17 & 4.08 & 4.53 & 4.93 \\
\hline $\mathrm{SO}_{4}{ }^{2-}[\mathrm{mg} / \mathrm{L}]$ & 267 & 337 & 167 & 184 & 204 & 150 & 251 & 268 \\
\hline $\mathrm{Ag}[\mathrm{mg} / \mathrm{L}]$ & 0.0033 & ND & 0 & $<0.3$ & $<0.3$ & 0 & $<0.3$ & $<0.3$ \\
\hline $\mathrm{Cd}[\mathrm{mg} / \mathrm{L}]$ & 0.0065 & ND & 0 & $<0.2$ & 0.2 & 0 & 0.20 & 0.3 \\
\hline $\mathrm{Cr}[\mathrm{mg} / \mathrm{L}]$ & 0.01 & $\mathrm{ND}$ & 0 & $<7$ & 8 & 0 & 10.0 & 18 \\
\hline $\mathrm{Cu}[\mathrm{mg} / \mathrm{L}]$ & 0.05 & ND & 0 & $<5$ & 5 & 10 & 10.5 & 11.0 \\
\hline $\mathrm{Ni}[\mathrm{mg} / \mathrm{L}]$ & 0.03 & ND & 9 & 9.75 & 11.0 & 11 & 13.8 & 19 \\
\hline $\mathrm{Pb}[\mathrm{mg} / \mathrm{L}]$ & 0.0054 & ND & 0 & $<1.2$ & $<1.2$ & 0 & $<1.2$ & $<1.2$ \\
\hline
\end{tabular}

a) Average results in September 2003 except for the data of field influent, which are the measured results of a composite sample of three grab samples taken from sprinkling wastewater.

b) Plant influent is wastewater before entering the plant; field influent is wastewater after being sprinkled before entering into the soil of each field.

c) ND not determined.

crease as much as exchangeable $\mathrm{Ca}$. The exchangeable $\mathrm{Mg}$ in the soils has also increased, especially in Rubicon soil. Additional analyses on soils sampled in 1973, 1976, and 1977 indicate that the soil at the site can achieve its equilibrium for $\mathrm{Ca}$ adsorption after just a few years of wastewater application (see Fig. 1). Once the equilibrium for $\mathrm{Ca}$ and $\mathrm{Mg}$ adsorption is reached, the $\mathrm{Ca}$ and $\mathrm{Mg}$ concentrations in field influent (i.e., wastewater before being sprayed onto the field) and effluent of the field should be almost the same; results of this study confirm this inference $[19,20]$.

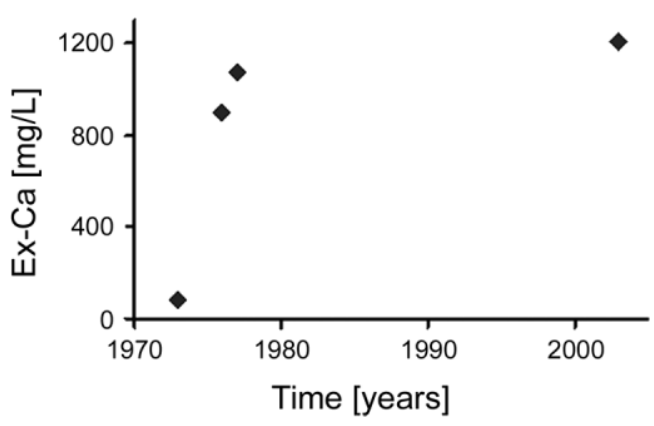

Figure 1. Accumulation of exchangeable Ca adsorbed in Roscommon soil.

\subsection{Profiles of Exchangeable Ca, Ca-/Mg-bound P, and $P_{\max }$}

The aforementioned results indicate that soil properties have been changed after long-term application of wastewater. These soil properties strongly affect the $\mathrm{P}$ fate and transport and the life expectancy of the Muskegon system. In this study, the effects of $\mathrm{Ca} / \mathrm{Mg}$ on $\mathrm{P}$ absorption in the soils and the relationship among the concentration of exchangeable $\mathrm{Ca} / \mathrm{Mg}$, the different forms of $\mathrm{P}$ (e.g., labile $\mathrm{P}$, Ca- and Mg-bound P, and total P absorbed in the soil), and the 1-day $\mathrm{P}_{\max }$ were evaluated. In the SR system, the concentration of labile $\mathrm{P}$ is very low in the Muskegon soils. The statistical analyses indicate that the labile $\mathrm{P}$ distribution is not correlated with any of the total P, Fe-bound $\mathrm{P}$, or Ca- \& Mg-bound $\mathrm{P}$ at the Muskegon site (data not shown).

As shown in Fig. 2, the exchangeable $\mathrm{Ca}$, Ca-bound $\mathrm{P}$, and $\mathrm{P}_{\max }$ for the Rubicon soil decrease with depth; Augers and Roscommon soils have similar profiles [20]. Most of $\mathrm{Ca}$ is accumulated in the $15 \mathrm{~cm}$ (6-in) deep topsoil (see Fig. 2), which coincides with the high TOC content there. Exchangeable $\mathrm{Ca}$ reduces very quickly in the first $60 \mathrm{~cm}$ (2-feet) near the top and reduces gradually after that. Because the exchangeable $\mathrm{Ca}$ and $\mathrm{Mg}$ are water soluble and rapidly ex- 
Table 2. Changes in chemical properties of $15-\mathrm{cm}$ topsoils ${ }^{\mathrm{a}}$.

\begin{tabular}{|l|c|c|c|}
\hline \multirow{2}{*}{ Properties } & \multicolumn{3}{|c|}{ Soil type } \\
\cline { 2 - 4 } & Rubicon & Augres & Roscommon \\
\hline $\mathrm{pH}^{\mathrm{a})}$ & $5.0 /(7.8 \pm 0.34)$ & $5.5 /(7.4 \pm 0.26)$ & $5.6 /(7.8 \pm 0.22)$ \\
\hline $\mathrm{Ex}^{-\mathrm{Ca}^{\mathrm{b})}}$ & $82 /(1205 \pm 45)$ & $310 /(1159 \pm 36)$ & $420 /(1359 \pm 47)$ \\
\hline $\mathrm{Total}^{-\mathrm{Ca}^{\mathrm{c}}}$ & $1800 /(2800 \pm 79)$ & $1800 /(2700 \pm 90)$ & $2700 /(4180 \pm 110)$ \\
\hline Ex-Mg & $8 /(72.5 \pm 15)$ & $49 /(76.5 \pm 11)$ & $78 /(98.5 \pm 17)$ \\
\hline $\mathrm{TOC}^{\mathrm{e})}$ & $0.93 /(1.74 \pm 0.11)$ & $1.14 /(1.84 \pm 0.15)$ & $1.48 /(2.68 \pm 0.14)$ \\
\hline $1-$ day $\mathrm{P}_{\max }^{\mathrm{f})}$ & $160 /(420 \pm 24)$ & $115 /(454 \pm 20)$ & $137 /(312 \pm 17)$ \\
\hline
\end{tabular}

a) All units are in $\mathrm{mg} / \mathrm{kg}$ soil except $\mathrm{pH}$ with no units. Any data before "/" is for year 1973 and after "/" for 2003 ( \pm standard deviation). $\mathrm{pH}, \mathrm{Ca}, \mathrm{Mg}, \mathrm{P}_{\max }$ values in 1973 are from an U.S. EPA report [2]. TOC in 1973 was measured in this study with the original soil sampled at 1973 (provided by the Muskegon plant). All data for 2003 were obtained from this study.

b) Exchangeable Ca.

c) Total Ca.

d) Exchangeable $\mathrm{Mg}$.

e ) Total organic carbon.

f) 1-day maximum $P$ sorption capacity.

changeable, they are ready to react with phosphate $[31,32]$. In the $\mathrm{SR}$ system, the $\mathrm{Ca}$ - and $\mathrm{Mg}$-bound $\mathrm{P}$ are the major form of $\mathrm{P}$ absorbed into the soils, accounting for $>70 \%$ of the total $\mathrm{P}$ absorbed in the soils. The Fe-bound $\mathrm{P}$ accounts for $\sim 20 \%$ of the total $\mathrm{P}$ in the SR soils. Therefore, $\mathrm{P}$ accumulation in the soil of a land treatment system is quite different from that in agricultural soil where $\mathrm{Fe}$ or $\mathrm{Al}$ usually binds $\mathrm{P}$ unless the soil is a calcareous soil.

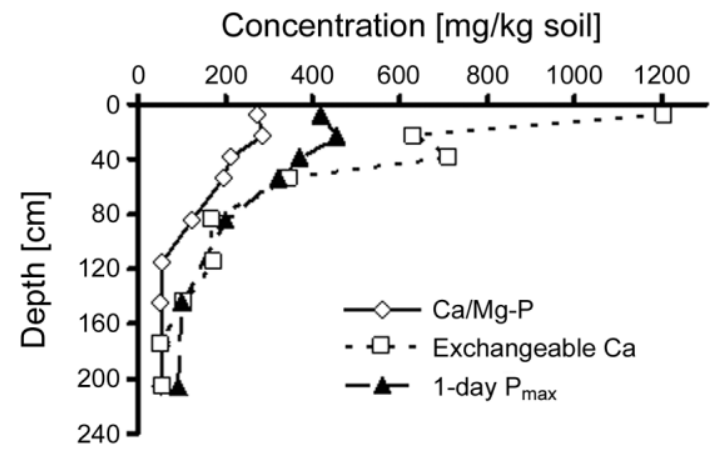

Figure 2. Profiles of exchangeable $\mathrm{Ca}, \mathrm{Ca} / \mathrm{Mg}$-bound $\mathrm{P}$, and 1-d $\mathrm{P}_{\max }$ in the Rubicon soil sampled in 2003. (Augers and Roscommon soils have similar profiles. Values and error bars (buried in the marks) represent the average and \pm one standard deviation, respectively, from triplicates of a composite sample at each depth for $\mathrm{Ca} / \mathrm{Mg}$-bound $\mathrm{P}$ and exchangeable $\mathrm{Ca}$.)

As shown in Tab. 2, the 1-day $\mathrm{P}_{\max }$ of the 15 -cm topsoils at the site has increased by 2-4 times as compared to that in 1973, which can be the major reason why the Muskegon system is so successful for $\mathrm{P}$ removal. While the 1-day $\mathrm{P}_{\max }$ decreases along the depth (see Fig. 2), a larger 1-day $\mathrm{P}_{\max }$ corresponds to a higher concentration of exchangeable $\mathrm{Ca}$ (see Fig. 2). Regression analysis shows that the 1-day $\mathrm{P}_{\max }$ is influenced by the quantity of exchangeable $\mathrm{Ca}$ adsorbed in the soil $\left(\mathrm{R}^{2}=0.71-0.93\right.$ for the three soils, [19]). Therefore, the exchangeable Ca may be a useful parameter for predicting the 1-day $\mathrm{P}_{\max }$ of the soils.

\subsection{Plant Available $P$ and Total Net Accumulated $P$ at the Muskegon Site}

As indicated by Eq. (1), the $\mathrm{P}_{\text {total }}$ is highly related to crop yield. In this study, it was found that, although the corn (Zea mays L. subsp. mays) production has increased in the last ten years, it still has not reached the expected maximum yield (i.e., $\sim 5.28 \mathrm{~m}^{3}$ corn/acre $[2,18]$ ). In fact, most of the fields just yielded one half (or even lower than that) of the expected maximum yield. While the very sandy soil and climate on the site could be two of the major reasons for such a low corn production, the deficiency of plant available $\mathrm{P}$ at each field is a factor that needs to be evaluated closely. On the basis of an U.S. EPA study, only the Rubicon soil contained adequate plant available $\mathrm{P}$ initially in 1973 [18]. It was anticipated that the $\mathrm{P}$ in wastewater would increase the soil $\mathrm{P}$ level within a few years since the start of the operation so that all soils would have enough $\mathrm{P}$ to support crop growth. However, the concentrations of plant available $\mathrm{P}$ in the three types of the soils have not increased much at all (see Tab. 3). Because 30 40 mg/kg soil of plant available $\mathrm{P}$ is adequate for the yield of $5.28 \mathrm{~m}^{3}$ corn/acre $[2,18]$, most of the Muskegon fields are short of plant available P.

However, the $\mathrm{P}_{\text {total }}$ has continuously accumulated in the soil even though the plant available $\mathrm{P}$ did not change much (see Fig. 3). The net $\mathrm{P}$ accumulated in the Rubicon soil increased from $\sim 700$ in 1993 to $\sim 1345 \mathrm{~kg} / \mathrm{ha}$ soil in 2001 , but the plant available $\mathrm{P}$ varied between $\sim 100-500 \mathrm{~kg} / \mathrm{ha}$ soil during the same period, indicating a large amount of the applied $\mathrm{P}$ has become the fixed $\mathrm{P}$ that is unavailable to plants. 
Table 3. Comparison of plant available $\mathrm{P}$ in top 1-m soils between 1973 and 2003.

\begin{tabular}{|c|c|c|}
\hline \multirow{2}{*}{ Soil type } & \multicolumn{2}{|c|}{ Plant available P [mg/kg soil] } \\
\cline { 2 - 3 } & 1973 & 2003 \\
\hline Rubicon & $32 \sim 45$ & $25 \sim 33$ \\
\hline Augres & $11 \sim 17$ & $10 \sim 17$ \\
\hline Roscommon & $5 \sim 15$ & $<5$ \\
\hline
\end{tabular}

For example, a final stable form of the $\mathrm{P}$ fixed by the $\mathrm{Ca}$ in the soil may be a secondary fluorapatite, which is difficult to be used by crops. Fluorapatite is formed more rapidly in the alkaline and neutral soil. At the Muskegon site, the soil is neutral and/or slightly alkaline, which may accelerate the formation of unavailable $\mathrm{P}$. Therefore, it will be difficult to remove the net accumulated $\mathrm{P}$ in the soil by simply increasing the crop yield.

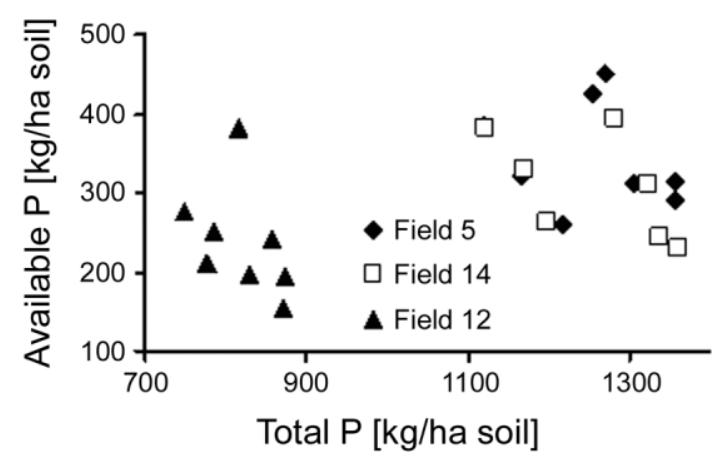

Figure 3. Relationship between total net accumulated and plant available $\mathrm{P}$ in the Rubicon soil. (Averages of data obtained from 1993 to 2001 are reported.)

\subsection{Long-Term P Sorption Isotherm Tests}

In light of the above discussion, a large amount of the applied $\mathrm{P}$ becomes the fixed $\mathrm{P}$ that is unavailable to plants. In the literature, the fixed $\mathrm{P}$ is often treated as precipitated $\mathrm{P}$ in the soil. It has been reported that the reaction of phosphate with soil surface involves adsorption of a small amount of phosphate followed by precipitation of calcium phosphate at a higher level $[4,5,9]$. The initial adsorbed $\mathrm{P}$ acts as nuclei for subsequent crystal growth. These nuclei might be in an amorphous form of calcium phosphate, which is slowly transformed into crystalline calcium phosphate [9]. Because the fixed $P$ is the $P$ that actually uses the soil $\mathrm{P}$ adsorption capacity, and therefore, is more closely related to the life expectancy of the soil, it is important to evaluate the maximum $\mathrm{P}$ adsorption capacity of the soil by including both the fast adsorption and slow transformation process.

In this study, long-term $\mathrm{P}$ sorption isotherm tests were conducted to approach this objective and to evaluate the $\mathrm{P}_{\max }$ of the Muskegon's soils as a function of absorption time in batch tests. Specific attention was given to include the effects of $\mathrm{Ca}$ sorbed onto the soils on the $\mathrm{P}_{\max }$ by using soils sampled at the same depth and with the similar concentration of the exchangeable $\mathrm{Ca}$. Soils at the depth of $0-31 \mathrm{~cm}$ contained 917 and $830 \mathrm{mg} / \mathrm{kg}$ exchangeable $\mathrm{Ca}$, and at 137-152 cm contained 102 and $106 \mathrm{mg} / \mathrm{kg}$ for the Rubicon soil and Augres, respectively. The results obtained from one set of these tests are presented in Fig. 4.

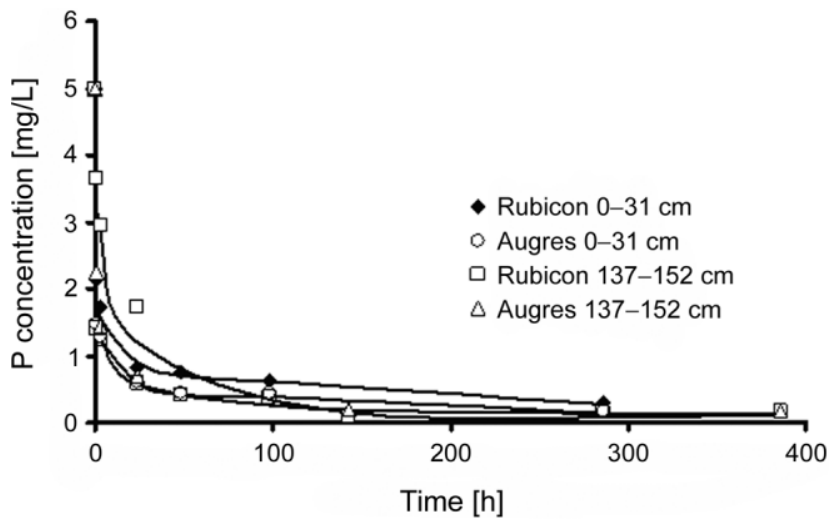

Figure 4. Time courses of liquid $P$ concentrations in one set of the long-term $\mathrm{P}$ sorption isotherm tests (test conditions: the initial $\mathrm{P}$ concentration, $\left.\mathrm{P}_{0} 5 \mathrm{mg} / \mathrm{L}\right)$.

The scheme of the phosphorus adsorption and reaction in a batch reactor can be described by the Langmuir-Hinshelwood model as follows [7] $]^{1)}$

$\mathrm{P}+\mathrm{S} \underset{\mathrm{K}_{\mathrm{d}}}{\stackrel{\mathrm{K}_{\mathrm{a}}}{\rightleftarrows}} \mathrm{A} \stackrel{\mathrm{K}_{\mathrm{r}}}{\rightarrow} \mathrm{F}+\mathrm{S}$

where $\mathrm{P}=\mathrm{P}$ concentration in liquid $[\mathrm{mg} / \mathrm{L}] ; \mathrm{S}=$ concentration of available sites for $\mathrm{P}$ adsorption $[\mathrm{mg} / \mathrm{L}] ; \mathrm{A}=$ concentration of adsorbed $\mathrm{P}[\mathrm{mg} / \mathrm{L}] ; \mathrm{F}=$ concentration of fixed $\mathrm{P}[\mathrm{mg} / \mathrm{L}] ; \mathrm{K}_{\mathrm{a}}=$ rate coefficient for adsorption $[\mathrm{l} / \mathrm{mg} / \mathrm{h}]$; $\mathrm{K}_{\mathrm{d}}=$ rate coefficient for desorption $\left[\mathrm{h}^{-1}\right]$; and $\mathrm{K}_{\mathrm{r}}=$ rate coefficient for precipitation $\left[\mathrm{h}^{-1}\right]$. According to Eq. (2), the kinetics equations are:

$\mathrm{dP} / \mathrm{dt}=-\mathrm{K}_{\mathrm{a}} \times \mathrm{S} \times \mathrm{P}+\mathrm{K}_{\mathrm{d}} \times \mathrm{A}$

$\mathrm{dA} / \mathrm{dt}=\mathrm{K}_{\mathrm{a}} \times \mathrm{S} \times \mathrm{P}-\mathrm{K}_{\mathrm{d}} \times \mathrm{A}-\mathrm{K}_{\mathrm{r}} \times \mathrm{A}$

$\mathrm{S}=\mathrm{S}_{0}-\mathrm{A}$

where $\mathrm{S}_{0}=$ initial concentration of available sites for $\mathrm{P}$ adsorption $[\mathrm{mg} / \mathrm{L}]$. Assuming that the reaction from $\mathrm{A}$ to $\mathrm{F}$ is slow compared to adsorption and desorption, Eq. (2) leads to rapid apparent equilibrium between solution and surface

1) List of symbols at the end of the paper. 
phases followed by a slow reaction. The Langmuir equation can be derived [7]:

$\mathrm{P}_{0}-\mathrm{P}_{\mathrm{e}}=\frac{\mathrm{S}_{0} \times \mathrm{P}_{\mathrm{e}}}{\mathrm{K}+\mathrm{P}_{\mathrm{e}}}$

where $\mathrm{P}_{0}=$ initial $\mathrm{P}$ concentration $[\mathrm{mg} / \mathrm{L}] ; \mathrm{P}_{\mathrm{e}}=\mathrm{P}$ equilibrium concentration $[\mathrm{mg} / \mathrm{L}]$; and $\mathrm{K}=$ Langmuir coefficient $[\mathrm{mg} / \mathrm{L}]$, which is given by:

$\mathrm{K}=\mathrm{K}_{\mathrm{d}} / \mathrm{K}_{\mathrm{a}}$

In this study, the previously reported methods [7] were followed to estimate the kinetic parameters. Briefly, $\mathrm{S}_{0}$ and $\mathrm{K}$ were estimated by fitting the data obtained from the first $24 \mathrm{~h}$ of the long-term tests with Eq. (6), that is, $1 /\left(\mathrm{P}_{0}-\mathrm{P}_{\mathrm{e}}\right)=\mathrm{K} /\left(\mathrm{S}_{0} \times \mathrm{P}_{\mathrm{e}}\right)+1 / \mathrm{S}_{0}$. As shown in Fig. 5, a plot of $1 /\left(\mathrm{P}_{0}-\mathrm{P}_{\mathrm{e}}\right)$ vs. $1 / \mathrm{P}_{\mathrm{e}}$ is drawn linearly. With Rubicon's topsoil as an example, $\mathrm{K}_{\mathrm{a}}$ and $\mathrm{K}_{\mathrm{r}}$ can be estimated as follows. For the fast adsorption process, data at $\mathrm{t}=0$ and $1 \mathrm{~h}$ (see Fig. 4) and Eq. (3) can be used:

$\mathrm{dP} / \mathrm{dt}=(2.1-5) \mathrm{mg} / \mathrm{L} /(1-0) \mathrm{h}=-2.9 \mathrm{mg} / \mathrm{L} \times \mathrm{h}=$ $-\mathrm{K}_{\mathrm{a}} \times \mathrm{S}_{0} \times 3.5 \mathrm{mg} / \mathrm{L}$

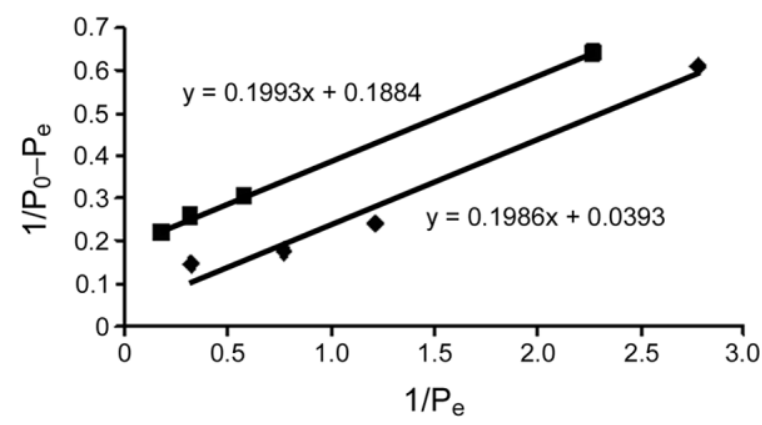

Figure 5. Estimation of $S_{0}$ and $\mathrm{K}$ by curve fitting. (The data points are the batch test results of the first $24 \mathrm{~h}$ of the long-term isotherm tests. The Rubicon soil sampled at the depth of $0-31 \mathrm{~cm}(\bullet)$ and $137-152 \mathrm{~cm}(\boldsymbol{\square})$ were used in these tests.)

Notice that $\mathrm{S}_{0}=25 \mathrm{mg} / \mathrm{L}$ (see Tab. 4), therefore,

$\mathrm{K}_{\mathrm{a}}=2.9 /(25 \times 3.5)=0.03 \mathrm{~L} / \mathrm{mg} \times \mathrm{h} ;$ and

$\mathrm{K}_{\mathrm{d}}=\mathrm{K} \times \mathrm{Ka}=5 \times 0.03=0.15 \mathrm{~h}^{-1}$

For the slow transformation process, data at $\mathrm{t}=24$ (see Fig. 4) and $48 \mathrm{~h}$ can be used:

$\mathrm{dP} / \mathrm{dt}=(0.43-0.6) \mathrm{mg} / \mathrm{L} /(48-24)=-0.9 \mathrm{mg} / \mathrm{L} \times \mathrm{h}=-\mathrm{K}_{\mathrm{r}} \times \mathrm{S}_{0}$ $\mathrm{K}_{\mathrm{r}}=0.0006 \mathrm{~h}^{-1}$

It should be pointed out that using $24 \mathrm{~h}$ and a longer time to estimate $\mathrm{K}_{\mathrm{r}}$ would give a result very similar to the above estimation. However, estimation of $\mathrm{K}_{\mathrm{a}}$ requires using an optimization technique to find the $\mathrm{K}_{\mathrm{a}}$ that can best fit the experimental data because the liquid $\mathrm{P}$ concentration drops so rapidly that visual inspection alone cannot guarantee the quality of the estimated parameter. Results of parameter estimation are presented in Tab. 4 , in which each parameter was the average of the parameter estimated from each of the three tests with an initial $\mathrm{P}_{0}=5,7$, and $10 \mathrm{mg} / \mathrm{L}$, respectively.
Table 4. Estimated $\mathrm{S}_{0}, \mathrm{~K}, \mathrm{~K}_{\mathrm{a}}, \mathrm{K}_{\mathrm{d}}$, and $\mathrm{K}_{\mathrm{r}}$ for Rubicon and Augres soil ${ }^{\mathrm{a}}$.

\begin{tabular}{|l|c|c|c|c|}
\hline \multirow{2}{*}{ Parameter } & \multicolumn{2}{|c|}{ Depth of Rubicon [cm] } & \multicolumn{2}{c|}{ Depth of Augres [cm] } \\
\cline { 2 - 5 } & $0-31$ & $137-152$ & $0-31$ & $137-152$ \\
\hline $\mathrm{S}_{0}[\mathrm{mg} / \mathrm{L}]$ & 25 & 5.5 & 13 & 7 \\
\hline $\mathrm{K}[\mathrm{mg} / \mathrm{L}]$ & 5 & 0.8 & 2 & 0.5 \\
\hline $\mathrm{K}_{\mathrm{a}}[\mathrm{L} / \mathrm{mg} \times \mathrm{h}]$ & 0.05 & 0.08 & 0.08 & 0.12 \\
\hline $\mathrm{K}_{\mathrm{d}}\left[\mathrm{h}^{-1}\right]$ & 0.25 & 0.06 & 0.16 & 0.06 \\
\hline $\mathrm{K}_{\mathrm{r}}\left[\mathrm{h}^{-1}\right]$ & 0.0006 & 0.0004 & 0.0005 & 0.0006 \\
\hline
\end{tabular}

a) Results are obtained from the long-term isotherm tests $(0-389 \mathrm{~h})$. $\mathrm{S}_{0}$ initia concentration of available sites for $\mathrm{P}$ adsorption; KLangumuir coefficient $\mathrm{K}_{\mathrm{d}} / \mathrm{K}_{\mathrm{a}} ; \mathrm{K}_{\mathrm{a}}$ rate coefficient for adsorption; $\mathrm{K}_{\mathrm{d}}$ rate coefficient for desorption; and $\mathrm{Kr}$ rate coefficient for precipitation.

It is difficult to completely differentiate the adsorption, desorption and precipitation processes from each other because these processes are all tangled together. Nevertheless, the long-term isotherm tests and the estimated parameters do provide the following new insights about $\mathrm{P}$ sorption at the Muskegon site. (i) For both soils, the topsoil contains more available sites for $\mathrm{P}$ adsorption. Near the top, Rubicon soil has more total sites than Augres, but the two soils have similar sites for $\mathrm{P}$ adsorption in the depth of $137-152 \mathrm{~cm}$. (ii) For both soils, the subsurface soil has a precipitation rate coefficient $\left(\mathrm{K}_{\mathrm{r}}\right)$ similar to the topsoil. The rate coefficient for $\mathrm{F}$ formation $\left(\mathrm{K}_{\mathrm{r}}\right)$, which presumably represents a slow transformation process of initial adsorbed $\mathrm{P}$ into crystalline phosphate [5], is almost the same for the four soil samples. (iii) The topsoil has a higher $\mathrm{K}_{\mathrm{d}}$, and therefore, is more vulnerable for $\mathrm{P}$ desorption than the deeper soil. (iv) Although the topsoil has a higher $\mathrm{P}$ adsorption capacity (i.e., a higher $\mathrm{S}_{0}$ ), the unit available rate coefficient for $\mathrm{P}$ adsorption $\left(\mathrm{K}_{\mathrm{a}}=(\mathrm{dP} / \mathrm{dt}) /(\mathrm{S} \times \mathrm{P})\right.$, Eq. (3) if desorption is not considered $)$ of the subsurface soil is slightly larger, which means the active sites in the subsurface soil would react faster with liquid phosphate. This inference is important to improve the $\mathrm{P}$ transport model. All the $\mathrm{P}$ transport models assumed the soil exhibited homogenous adsorption kinetics along the depth, which is obviously not close to the real condition. Considering the lower desorption rate coefficient and the higher adsorption rate coefficient at deeper soil, $\mathrm{P}$ leaching would not happen until all the available sites at deeper soil are occupied.

One important observation in the long-term isotherm tests was that the $\mathrm{P}_{\max }$ increased with the adsorption time during the batch tests $[19,20]$. For Rubicon and Augres topsoils $(0-31 \mathrm{~cm})$, the $\mathrm{P}_{\max }$ increased from $\sim 430$ at $\mathrm{t}=24 \mathrm{~h}$ (see Tab. 2) to $\sim 900$ at $\mathrm{t}=1000 \mathrm{~h}$, and to $>1000 \mathrm{mg} / \mathrm{kg}$ soil at $\mathrm{t}=1900 \mathrm{~h}$. For both types of deep soils $(137-152 \mathrm{~cm})$, the $\mathrm{P}_{\max }$ increased from $\sim 100$ at $\mathrm{t}=24 \mathrm{~h}$ to $\sim 250$ at $\mathrm{t}=390 \mathrm{~h}$. The $\mathrm{P}_{\max }$ did not approach its maximum value even after 390- and 2000-h adsorption for the soils at two different depths [19]. These results are consistent with previous reports, in which the real $\mathrm{P}$ adsorption capacity in the field was 
estimated to be about 3-5 times higher than that of the estimated 1-day $\mathrm{P}_{\max }[1,33]$. The results of the $\mathrm{P}_{\max }$ tests indicate that it is possible for the soil to continuously adsorb $\mathrm{P}$, and it is difficult to obtain an absolute $\mathrm{P}_{\max }$ with isotherm tests within a reasonably short period.

\subsection{Life Expectancy of the System}

Tab. 5 shows the comparison between the Muskegon's predication on the life expectancy of the Muskegon site and the predication based on the results of this study. The Muskegon's prediction used the 1-day $\mathrm{P}_{\max }$ values of the original soils sampled in 1973. These values were provided by the Muskegon plant, and they are similar to the values shown in Tab. 2. The prediction of this study used the 1-day $\mathrm{P}_{\max }$ values obtained from soils sampled in 2003 (see Tab. 2). The $P_{\text {total }}$, defined by Eq. (1), are based on the record of 27-year operation (i.e., from 1973 to 2001) and total $\mathrm{P}$ mass balance calculations. The used $\mathrm{P}$ sorption capacity (UPSC) is the measured total P in soils sampled in 2003 [20], which has been absorbed in the soil. Both predications assume that the P build-up rate is constant each year. It should be pointed out that the $\mathrm{P}$ contents in the original soils before applying wastewater was not included in the Muskegon's prediction; if they were included, most of the fields should have been close to be saturated by $\mathrm{P}$ based on the 1-day $\mathrm{P}_{\max }$ values provided by the Muskegon Plant.

A computer model has been developed in this study [34]. To use the model to predict the life expectancy of each field, several coefficients and constants are needed, such as soil's 1-day $\mathrm{P}_{\max }$, $\mathrm{P}$ content in selected crops, dry soil bulk density, and the drainage rate. In addition, the operation conditions of the land treatment system are needed, such as the crop type, crop yield, irrigation rate, $\mathrm{P}$ concentration in the irrigation water, and precipitation data. On the basis of this model and the new 1-day $\mathrm{P}_{\max }$ values of this study, it was found that the life expectancy of each field at the Muskegon site has been extended significantly since 1974 (see Tab. 5).

The estimated life expectancies in Tab. 5 are calculated by assuming the whole soil layer of a 152-cm thickness having a 1-day $\mathrm{P}_{\max }$ of the $15-\mathrm{cm}$ topsoil. Modifications can be made by considering each sub-layer of the soil having a different 1-day $\mathrm{P}_{\max }$; in this way, the estimated life expectancies will be shorter than those shown in Table 5. In this paper, these modified life expectancies are not presented because the method of using 1-day $\mathrm{P}_{\max }$ to do the calculation could be wrong. In other words, the life expectancy of the Muskegon site would have been much longer if the $\mathrm{P}_{\max }$ obtained from the long-term isotherm tests had been used for the calculation. However, information collected from the long-term isotherm tests is not enough to provide the $\mathrm{P}_{\max }$ values of each sub-layer. Further studies are needed.

Results of the long-term $\mathrm{P}$ sorption tests indicate that $\mathrm{P}$ sorption in the soil consists of a fast adsorption and a slow transformation process. Although it is very difficult to estimate how the slow transformation process would enhance the $\mathrm{P}$ sorption capacity as a function of time and the soil depth, the slow process does provide a mechanism for soil to retain more $\mathrm{P}$. Also considering that the ground water table at the Muskegon site can be $>2-3 \mathrm{~m}$, and the saturated zone below the ground water table may still adsorb $\mathrm{P}$, the estimated life expectancies based on the results of this study (see Tab. 5) can be viewed to be reasonable with a great safety margin.

\section{Summary}

The overall performance of the Muskegon land treatment system is excellent. The records show that the land treatment system has been successful in generating high quality effluent, with total $\mathrm{P}$ and BOD consistently lower than $0.03 \mathrm{mg} / \mathrm{L}$ and $5 \mathrm{mg} / \mathrm{L}$, respectively. The long-term application of wastewater has changed the chemical properties of the soil. Specially, changes in soil $\mathrm{pH}$ and the amount of $\mathrm{Ca}$ absorbed by the soil are significant.

The amount of $\mathrm{Ca} / \mathrm{Mg}$ absorbed in the soil affects the $\mathrm{P}$ adsorption capability of the soil; Ca- and Mg-bound $\mathrm{P}$ accounts for $>70 \%$ of the total $\mathrm{P}$ adsorbed in the soil. While most of the applied $\mathrm{P}$ has been accumulated in the topsoil at the Muskegon site, different forms of $\mathrm{P}$ were found in deeper soils. The soil's maximum $\mathrm{P}$ sorption capacity has been increased by $\sim 2-4$ times based on the results of 1-day adsorption batch tests.

Results of the long-term $\mathrm{P}$ sorption isotherm tests indicate that the actual maximum $\mathrm{P}$ sorption capacity of the Muskegon soil could be 2-5 times higher than that obtained from 1-day adsorption batch tests of this study; $\mathrm{P}$ sorption in the soil consists of a fast adsorption and a slow transformation process. The life expectancy of the Muskegon land treatment system has been extended significantly with the application of wastewater. 


\section{Acknowledgements}

This research was supported by the U.S. Environmental Protection Agency Region 7 (Project \#: 3K-3176-NAEX) with the matching fund provided by the College of Engineering and Technology at the University of Nebraska-Lincoln.

Received: August 27, 2005 Received in revised form: January 6, 2006 Accepted: January 23, 2006

\section{Symbols used}

$\begin{array}{lll}\mathrm{K} & {[\mathrm{mg} / \mathrm{L}]} & \text { Langmuir coefficient }\left(\mathrm{K}_{\mathrm{d}} / \mathrm{K}_{\mathrm{a}}\right) \\ \mathrm{K}_{\mathrm{a}} & {[\mathrm{l} / \mathrm{mg} / \mathrm{h}]} & \text { rate coefficient for adsorption } \\ \mathrm{K}_{\mathrm{d}} & {\left[\mathrm{h}^{-1}\right]} & \text { rate coefficient for desorption } \\ \mathrm{K}_{\mathrm{r}} & {\left[\mathrm{h}^{-1}\right]} & \text { rate coefficient for precipitation } \\ \mathrm{P}_{\mathrm{e}} & {[\mathrm{mg} / \mathrm{L}]} & \text { P equilibrium concentration } \\ \mathrm{P}_{0} & {[\mathrm{mg} / \mathrm{L}]} & \text { initial P concentration } \\ \mathrm{S}_{0} & {[\mathrm{mg} / \mathrm{L}]} & \text { initial concentration of available sites } \\ & & \text { for P adsorption }\end{array}$

\section{Abbreviations}

(BOD) biochemical oxygen demand

$\left(\mathrm{P}_{\max }\right) \quad$ soil's maximum $\mathrm{P}$ sorption capacity

$\left(\mathrm{P}_{\text {total }}\right) \quad$ total net accumulated $\mathrm{P}$ in the soil

(TOC) soil's total organic carbon

\section{References}

[1] Process Design Manual - Land Treatment of Municipal Wastewater (Ed U.S. EPA), U.S. EPA 625/1-81-013 (COE EM 1110-1-501), Center for Environmental Research Information, U.S. EPA, Cincinnati, OH, 1981.

[2] B. G. Ellis, A. E. Erickson, A. R. Wolcott, B. D. Knezak, J. M. Tiedje, J. Butcher, Applicability of land treatment of wastewater in the great lakes area basin: effectiveness of sandy soils at Muskegon County, Michigan, for renovating wastewater, in U.S. EPA Rep. 905/9-79-006-B, U.S. Gov. Print. Office, Washington, DC, USA, 1979.

[3] C. G. Enfield, C. C. Harlin, Jr., B. E. Bledsoe, Comparison of five kinetic models for orthophosphate reactions in mineral soils, Soil Sci. Soc. Am. J. 1976, 40, 243-249.

[4] C. V. Cole, S. R. Olsen, C. O. Scott, The nature of phosphate sorption by calcium carbonate, in Proceedings of the Soil Science Society of America 1953, $17,352-356$

[5] J. S. Freeman, D. L. Rowell, The adsorption and precipitation of phosphate onto calcite, J. Soil Sci. 1981, 32, 75-84.

[6] H. C. B. Hansen, P. E. Hansen, J. Magid, Empirical modeling of the kinetics of phosphate sorption to macropore material in aggregated subsoils, Euro. J. Soil Sci. 1999, 50, 317-327.

[7] A. R. Overman, R. V. Scholtz, Langmuir-Hinshelwood model of soil phosphate kinetics, Commun., Soil. Sci. Plant Anal. 1999, 30, 109-119.

[8] N. J. Barrow, On the reversibility of phosphate sorption by soils, J. Soil Sci. 1983, 34, 751-758

[9] W. Stumm, J. O. Leckie, Phosphate exchange with sediments; its role in the productivity of surface water, in Proceedings of the 5th International Pollution Research Conference, Section III-26, 1-9, Pergamon, San Francisco, USA, 1970.
[10] C. G. Enfield, B. E. Bledsoe, Fate of wastewater phosphorus in soil, J. Irrig. Drain. Div. (ASCE) 1975, 101, 145-155.

[11] C. G. Enfield, L. E. Leach, Phosphorus model of Muskegon wastewater system, J. Environ. Eng. Div. (ASCE) 1975, 101, 911-916.

[12] A. R. Overman, R. L. Chu, W. G. Leseman, Phosphorus transport in packed-bed reactor, J. Water Pollut. Control Fed. 1976, 48, 880-888.

[13] C. G. Enfield, T. Phan, D. M. Walters, R. J. Ellis, Jr., Kinetic model for phosphate transport and transformation in calcareous soils: I. Kinetics of transformation, Soil Sci. Soc. Am. J. 1981, 45, 1059-1064.

[14] C. F. Lin, W. J. Busscher, D. Lowell, Simulated effects of flow rate on phosphate retention in soils, Math. Comp. Simul. 1983, 25, 430-435.

[15] R. S. Mansell, P.J. Mckenna, E. Flaig, M. Hall, Phosphate movement on columns of sandy soil from a wastewater-irrigated site, Soil Sci. $\mathbf{1 9 8 5}$ $140,59-68$.

[16] J. Vanderborght, D. Jacques, J. Feyen, Deriving transport parameters from transient flow leaching experiments by approximate steadystate flow convection-dispersion models, Soil Sci. Soc. Am. J. 2000, 64 , $1317-1327$.

[17] USDA, Soil Surveys: Muskegon County Michigan, Michigan State Conservationist, East Lansing (MI), USA, issued October 1968.

[18] C. M. Biegel, L. S. Lee, J. G. Graveel, J. J. Vorst, Muskegon County wastewater management: an effluent application decision case study, J. Nat Resour. Life Sci. Edu. 1998, 27, 137-144.

[19] C. Hu, Phosphorus sorption capacity and distribution in soils of Muskegon Wastewater Land Treatment System, M.S. Thesis, University of Nebraska-Lincoln, Lincoln, NE, USA, 2005.

[20] C. Hu, T. C. Zhang, Y.H. Huang, M. F. Dahab, R. Surampalli, Effects of long-term wastewater application on chemical properties and phosphorus adsorption capacity in soils of a wastewater land treatment system, Environ. Sci. Technol. 2005, 39, 7240-7245.

[21] Methods of Phosphorus Analysis for Soils, Sediments, Residuals, and Waters (Ed: G. M. Pierzynski), Southern Cooperative Series Bulletin No. \#396. URL, North Carolina State University, USA, 2000. (http:// www.soil.ncsu.edu/sera17/publications/sera17-2/ pm_cover.htm)

[22] K. Pettersson, V. Istvanovics, Sediment phosphorus in Lake Balatonforms and mobility, Ergebn. Limnol. 1988, 30, 25-41.

[23] V.D. Nair, D. A. Graetz, K. M. Portier, Forms of phosphorus in soil profiles from dairies of south Florida., Soil Sci. Soc. Am. J. 1995, 59, 1244-1249.

[24] S. R. Olsen, L. E. Sommers, Phosphorus, in Methods of Soil Analysis, Part 2, 2nd ed. (Eds: A. L. Page, R. H. Miller, D. R. Keeney), Agronomy No. 9. American Society of Agronomy Madison (WI), USA, 1982, 403-430.

[25] R. K. Schofield, A.W. Taylor, The measurement of soil pH, Soil Sci. Soc. Am. Proc. 1955, 19, 164-167.

[26] J. A. McKeague, J.H. Day, Dithionate and oxalate-extractable Fe and $\mathrm{Al}$ as aids in differentiating various classes of soils. Can. J. Soil Sci. 1966 $46,13-22$.

[27] E.O. McLean, Aluminum, in: Methods of Soil Analysis, part 2 (Ed: C.A. Black), Agronomy 9, Am. Soc. of Agron., Madison WI, USA, 1965 , 978-998.

[28] C. J. Schollenberger, R. H. Simon, Determination of exchange capacity and exchangeable bases in soil-ammonium acetate method, Soil Sci. 1945, 59, 13-24.

[29] B. E. Davies, Loss-on-ignition as an estimate of soil organic matter, Soil Sci. Soc. Amer. Proc. 1974, 38, 150-151.

[30] J. A. McKeague, B. H. Sheldrick, A comparison of some methods for determining carbonates in soils, Can. J. Soil Sci. 1976, 56, 125-127.

[31] A. R. Isensee, L. M. Walsh, Influence of banded fertilizer on the chemical environment surrounding the band. II. Effect on soil-solution cation, cation-anion balance and solution phosphorus, J. Sci. Food Agric. 1972, 23, 509-516.

[32] C. M. Cho, Phosphate transport in calcium-saturated systems: I. Theory, Soil Sci. Soc. Am. J. 1991, 55, 1275-1281.

[33] S.E. A. T. M. van der Zee, L. G. J. Fokkink, W. H. van Riemsdijk, A new technique for assessment of reversibly adsorbed phosphate, Soil Sci. Soc. Am. J. 1987, 51, 599-604.

[34] T. C. Zhang, M.F. Dahab, Phosphorus Sorption Capability and Distributions in Muskegon, MI's Soil for Long-Term Wastewater Land Treatment, Research Progress Report submitted to the U.S. EPA, Civil Eng. Dept., University of Nebraska-Lincoln, Lincoln, NE, USA, 2003. 